\title{
THE QUEST OF INDONESIAN MUSLIM IDENTITY Debates on Veiling from the 1920s to 1940s
}

\author{
Ali Tantowi \\ The Circle of Islamic and Cultural Studies, Jakarta
}

\begin{abstract}
This paper undertakes a debate of wearing veil for Muslim women among Indonesian Muslim scholars and role of modernist Muslims in propagating it in the early twentieth century. It shows that, the modernist Muslims' propagation on veil had massively started in the early twentieth century trough printed media and encountered fierce responses from others. In addition, the debate itself was influenced by similar trends in Middle Eastern countries, especially Egypt, which became the reference of Islamic current issues at the time. Because of the uncompromising propagation on veil, the debate not only stimulated polemics but also invited physical violence, which was proven to be unproductive for the campaign. Therefore, the spread of veil among Indonesian Muslim during those decades in Java was not significant with only few Muslim women who were affiliated to Modernist organization such as Muhammadiyah and Persis wore veils. The debate itself was not merely a contentious religious debate but also cultural debate which shows the quest of identity as being Indonesian and being Muslim at the same time. The issue of cutting off from Western cultural domination also spiced up the veiling debate.
\end{abstract}

Keywords: Indonesian Muslim identity, veil.

\section{Introduction}

Dress is one of human's primary needs; people wear it for protection, modesty and utility. Besides, dress also may function as a cultural statement; ${ }^{1}$ it becomes an important symbol of identity,

\footnotetext{
${ }^{1}$ See Yedida Kalfon Stillman, Arab Dress: A Short Story from the Dawn of Islam to Modern Times, ed. Norman A. Stillman (Leiden: Brill, 2000), p. 1
} 
showing many different aspects of culture. It can identify gender, age, social position, ethnic background, religion and regional background of the dressers. Moreover, some people demonstrate their ideology through their certain dress which draws debate and even causes physical violence. In its simple form, dress has existed and developed along with the life of humankind. Therefore dress becomes an important aspect in all cultures, especially in Muslim society.

During the last two centuries, the issue of Muslim dress, especially on veiling for women, has become one of the most contentious religious and cultural debates in the Muslim worlds, including Indonesia, and also in Western societies where they are relatively large communities of Muslims. ${ }^{2}$ This polemic not only attracts tension among people from different communities but also demands governments to make some regulations concerning the issue of Muslim dress, like what happened in Indonesia in the early 1980s when the government ban on wearing veil in state schools invited debates among Muslims and Government officials. Some Western and Indonesian scholars have written on the issue of veiling which most of their studies mainly focused and started from the 1980s to the present, whereas the polemic on veiling actually had become the hot debate since the nineteenth century.

The earliest tension and polemics caused by the issue of veiling in Indonesia presumably could be traced back to the early nineteenth century when adat and padri faction in Minangkabau were involved in contention that ended in a war, so called padri war (1821-1837 AD). Apparently influenced by Wahabism, Padri faction, the Muslim community who made pilgrimage to Mecca and returned, tried to put their version of interpretation of the Quran and shariah into their social life. They asked influential people in their community to inforce Islamic laws including dress codes. Finally, they inforced people to adopt Arab dress, arguing that adat dress (pakaian adat) was not suitable with Islam. Some related regulations are that men had to keep their beard and wear white clothes and women had to wear dress that completely covered their face. Whoever broke the regulation was to be sentenced by death penalty. ${ }^{3}$

\footnotetext{
2 Ibid., p. 153

3 One of the influential people who tried to apply the ruel was Tuanku Nan Renceh; his old aunt was sentenced to death because she broke one of the rules; see Muhamad
} 
This paper aims to show that the issue of veiling also became a contentious polemics in the first half of the twentieth century, focusing from the 1930s and the 1940s. It is hoped that the study will contribute to the history and dynamics of veiling in Indonesia, especially for the quest of Indonesian Muslim identity.

\section{The Emergence of Reformist Movements}

From the late nineteenth century to the early twentieth century, the transmission of Islamic modern ideas between Southeast Asia and Egypt was very intense. It was abridged by a reformist journal, alManar (1898-1836), edited by Rashid Ridha (1865-1935), ${ }^{4}$ the student of Muhammad 'Abduh (1849-1905). Rasyid Ridha successfully transmitted 'Abduh's legacy to Southeast Asia through the journal that mainly provoked Muslim to return back to the princples of Islam, the Quran and Sunna, and to the tradition of Salaf al-Shalih (pious forefther). The messages of al-Manar (the beacon), the renewal and reform, was positively appreciated by certain Indonesian ulama in Mecca, who was so-called the Jawi community. One of them is Ahmad Khatib (1860-1916) who tried to purify the religious practices of Indonesian Muslim traditions. ${ }^{5}$

Appreciated by several Muslim scholars, al-Manar then also became popular in Indonesia. There were many Muslim scholars who became interested in it; among them are Khatib's students, Shakh Tahir Jalal alDin (1869-1956), the editor of Singapore's al-Imam (1906-08) and Ahmad Dahlan. Another interested reader of al-Manar was Syekh Ahmad Surkatti (1872-1943), a Sudanese origin who was invited in 1911 by Jami'atul- Khair to teach in Indonesia. Influenced by al-Manar

Rajab, Perang Paderi di Sumatera Barat 1803-1838 (Jakarta: Perpustakaan Perguruan, Kementrian P \& K, 1954), pp. 16-17

4 Rashid Rida was a productive and influential author on Islamic reform, PanIslamism, and to some extent, also on Arab nationalism. Along with his teacher, Muhammad 'Abduh he published a journal dealing with Islamic reform, al-Manar and then he became the editor from its first issue of until his death, 1935; for further information, see "Rashid Rida," in H.A.R. Gibb, J.H. Kramers, E. Levi-provencal, and J. Schacht (eds), The Encyclopedia of Islam, VIII (Leiden: Brill, 1986), pp. 446-8.

5 That is why he was regarded by Steenbrink as "the master of first generation of reformist ulama in Malay-Indonesia." It is said that he also encouraged his students to read al-Manar. For further information, see Jajat Burhanuddin, "Aspiring for Islamic Reform: Southeast Asian Request for Fatwas in al-Manar," Islamic Law \& Society, Vol. 12, Issue 1 (Feb 2005): pp. 9-26; (cf. Kaptein 1995: pp. 141-60; and 1997). 
he left this organization dominated by 'alawi community after his criticism to their special position above non 'alawi Muslims. . Swiftly, al-Manar got its privilege from Indonesian Muslim intellectuals. They considered al-Manar as a relevant source of religious authority, as indicated by their preference to request fatwa from Rashid Ridha, instead of Meccan Ulama as they used to do. For instance, when a debate on Muslim dress in Minangkabau occured in the early twentieth century on the issue of whether a Muslim could adopt the clothes of Western people, there was a disagreement between Kaum Tua (old generation) and Kaum Muda (young generation). In conclusion, they eventually requested a fatwa from al-Manar which told that it was permitted. ${ }^{7}$

The passion of modernity and reforms in al-Manar influenced its readers to establish Muslim reformist organizations in the early of the twentieth century in Indonesia. ${ }^{8}$ Ahmad Dahlan, Ahmad Khatib's student, founded Muhammadiyah in 1912 in Kauman, Yogyakarta. Three Muslim traders who often discussed al-Manar in 1923 founded Persatuan Islam (the Islam union, Persis) in Bandung which later became the leading reformist organisation in the colonial era. ${ }^{9}$ Likewise, Ahmad Surkatti also founded a new modern organization in 1915, called, al-Ishlah wa al-Irsyad, to promote and preserve the tenets of Salafism orthodoxy. ${ }^{10}$

\footnotetext{
${ }^{6}$ An example of this superiority is the prohibition of marriage between a syarifah (an alawi's woman) and non-sayyid (non-'alawi man), Djohan Effendi, $A$ Renewal Without Breaking Tradition: the Emergence of a New Discourse in Indonesi'a Nabdlatul Ulama during Abdurrabman Wabid Era, (Yogyakarta: Interfidei, 2008), p. 46
}

7 See Nico J.G. Kaptein, "Southeast Asian Debates and Middle Eastern Inspiration: European Dress in West Sumatra at the Beginning of the Twentieth Century," in Eric Tagliacozzo (ed.), Southeast Asia and the Middle East: Islam, Movement, and the Longue Durée (Stanford: Stanford University Press), pp. 176-195.

8 Not all Muslim reformist scholars in Indonesia got involved in or established religious reformist movement; one of them was Muhammad Basyuni Imran (born in 1885) who became the supporter of Islamic reform in Egypt; he studied in Mecca and Cairo and became a student of Rashid Ridha; in 1913 he got the highest religious position in the kingdom of Sambas, West Kalimantan, as Maharaja Imam; see G.F. Pijper, Beberapa Studi Tentang Sejarah Islam di Indonesia 1900-1950, transl. Turjimah and Yessy Augusdin (Jakarta: Penerbit Universitas Indonesia, 1984), p. 142.

${ }_{9}^{9}$ Howard M. Federspiel, Islam and Ideology in the Emerging Indonesian State: The Persatuan Islam, 1923 to 1957 (Leiden: Brill, 2001), pp. 84-100.

${ }^{10}$ Effendi, A Renewal Without Breaking Tradition, p. 46 


\section{Tension with Muslim Traditionalists and Nationalist}

The emergence of these modernist and reformist organization started to irritate the harmony of religious life of Indonesian Muslims. There were only few incidents happened, like a pole whose water surface was calm. When Islamic reformist movements expanded their activities and flourished, a calm pole became a river with a heavy water current which whenever could overflow. ${ }^{11}$

The reformist's religious and even political views often invited traditionalist and nationalist Muslims into heated debates, sometimes with full of tension. In 1921 for instance, Haji Ahmad Sanusi in West Java issued a fatwa criticizing the tradition of slametan or tablilan and considering it as dhiyafah (tribute to idols of God) which was abhored by God and even it would became haram (forbidden) if slametan was considered as religious tradition since the Qur'an and the prophet Muhammad never encouraged it. This fatwa then was rejected by Raden Haji Uyek Abdullah, the leader of Pabuaran pesantren, claiming that the tradition of slametan was included in the catagory of sidekah (arabic: shadaqa) which was permitted by religion. ${ }^{12}$ The debate also had raised tension; for instance some people who opposed reformist movements frequently showed their hatred obviously, as indicated in Kudus, Central Java in 1926 when a father who married his daughter off asked her prospective husband to agree on his specific taklek (Arabic : ta'liq, which means divorce will automatically happen if the husband broke one of the agreements proposed in the time of marriage contract); $1^{13}$ if he eventually became member of Muhammadiyah his marriage would be abrogated.

The debate which occurred between nationalist and reformist Muslims can be seen, for instance, on the issue of Indonesian nationalism. Such debate involved the influential leader of Persatuan Islam (Persis), Ahmad Hassan, who argued that Islam did not recognized nationalism for Muslims. Instantly, the nationalist leader who later became the first Muslim president of Indonesia, Sukarno opposed it. In addition, the outspoken Muslim politician and scholar and Ahmad Hassan's student, Muhammad Natsir also always criticized Sukarno's ideas and get involved in polemics with him in the 1930s

\footnotetext{
11 Pijper, Beberapa Studi Tentang Sejarah Islam, p. 105

12 Kaoem Moeda, No. 42, March 2, 1921 and March 7, 1921.

13 Pijper, Beberapa Studi Tentang Sejarah Islam, p. 113.
} 
and the early 1940s. Deliar Noer asserted that "they represented the opinions of the two most important groups in Indonesia.., i.e., the Muslim and the religiously neutral nationalist." 14

The most crucial issue that contributed the debates and tensions among Indonesian Muslim was the preference of reformist Muslims to return to the Quran and Hadith as basic principles in justifying Indonesian Muslim traditions and culture. The main issue behind this slogan was among other things rejection of taqlid that lead to the rejections of some traditional Indonesian Muslim traditions, such as talkin, tablil and maulid nabi. ${ }^{15}$ The debate questioning how Muslim women should dress also occurred, concerning on the veiling, especially between the nationalist and reformist Muslims.

\section{Indonesian Muslim Women's Dress}

Most Indonesian Muslim women in Java in the early of twentieth century did not cover their head but they did cover during prayer or attend religious gatherings. This condition was probably influenced by the role of sufism in the early days of Islam in Indonesia because Sufism is generally seen as accommodative to local beliefs and practices. As a result, Indonesian Muslims became more sincretic in practicing Islam and did not vigilantly stressed on religious symbols such as headscarf. It apparently led to the assumption that headcover was obliged only in praying. Such assumption was indicated by many readers of some Islamic magazines at that time, like Aliran Baroe and alLisan, who questioned the obligation of headscarf, as I will explain in the next sections.

Before discussing the debates surrounding women veiling, it is noteworthy to highlight some Indonesian terminologies on Muslim women's dress available at the time. Predictably the terms have Arabic origin although with somewhat changes of spelling. I will only describe three most Indonesian terms of Indonesia Muslim women's dress.

\section{Berguk}

Berquk is borrowed from Arabic burqa which was defined as a long dress covering a woman's body and face which was usually worn by

\footnotetext{
14 See Deliar Noer, the Modernist Muslim Movement in Indonesia 1900-1942 (London: Oxford University Press, 1973), pp. 216-79.

${ }^{15}$ Karel A. Steenbrink, Pesantren, Madrasah, Sekolab: Pendidikan Islam dalam Kurun Modern (Jakarta: LP3ES, 1986), pp. 26-28.
} 
Muslim women in performing hajj. ${ }^{16}$ In the early $20^{\text {th }}$ century, this kind of cloth was presumably only limitedly worn Muslim women from Alawiyyin community who claimed as the descendants of the prophet Muhammad through Fatima's line. Since they were the honorable women, they deserved special treats including the matter of clothes.

Figure 1: Special cloth which was propagated by the berguk movement.

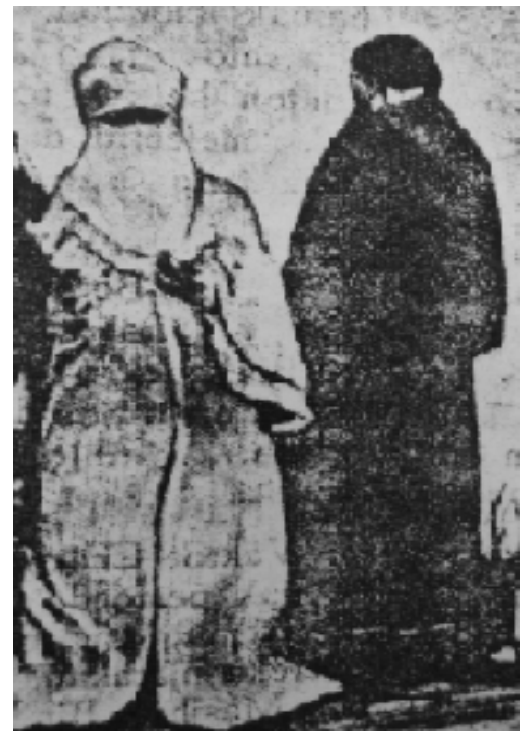

Source: Aliran Baroe, "Mana Dia? Bergoeknya Toean Bin Yahya Masyhoer,” No. 21 (1940), p. 19.

\section{Mukena}

Mukena is a special dress that covers a head and a half of body (sometimes whole body), worn by an Indonesian Muslim woman for daily prayers. When used in praying, mukena is worn along with a white

\footnotetext{
16 W.J.S. Poerwadarmita, Kamus Besar Babasa Indonesia (Jakarta: Perpustakaan Perguruan Kementrian P \& K, 1954), p. 96. According to Hauge Einar, such borrowing is called as a loanword which means a kind of word loaning that show complete morphemic importation. This importation then can be classified according to the degree of phonemic substitution that may occur with little, complete or without any change. Heah Lee Hsia classifies it as pure loanwords; it means that overall morphemic shape remain is its source language, without showing any fusion with the element of the recipient language. See Heah Lee Hsia, The Influence of English on the Lexical Expansion of Bahasa Malaysia (Kuala Lumpur: Dewan Bahasa dan Pustaka, 1989), p. 23.
} 
downward cloth wrapping another half body; some Muslim women who does not have a white downward cloth they will replace it with kain sarung or kain sembabyang; the Sundanese call it samping mukena. The term mukena is not only used in Indonesia, but also in Malaysia and Singapore, with an additional letter ' $h$ ' at the end of the word, mukenab. ${ }^{17}$

This term actually had been used by the Sundanese in the 1870s 18 and according Pijper, Malay people in Batavia (Jakarta) in the 1930s also have used this term to indicate a white veil for praying; whereas at that time other tribes were using different terms; for instance the Javanese called it rukub; ${ }^{19}$ the Acehnese called it selekom, selekong, telekom and telekong; ${ }^{20}$ in other Malay spoken lands called it telekung, ${ }^{21}$ and the people in Minangkabau call it tilakong22 or tilakuang. ${ }^{23}$

This term is also loanword from Arabic, miqna' (aقن) or miqnaá (مقفة); 24 it comes from the root word $q-n$-á that could mean 'to cover'. In Ibn al-Mandzur's Lisan al-Árab, mignaá is described as 'a dress used by women to cover her head and some part of her beautiful body'. ${ }^{25}$ When adapted to Indonesian language its meaning has changed as we can see in Kamus Besar Bahasa Indonesia (1988) that define mukena as "kain selubung kepala dan badan bagi wanita (dipakai ketika sembahyang); telekung" (a cloth covering the head and body of woman, used while in praying; also called, telekung $).{ }^{26}$

\footnotetext{
${ }^{17}$ See Safarwan, H. Zainal Abidin, Kamus Besar Bahasa Melayu (Kuala Lumpur: Utusan Publication and Distributor, 1995), p. 1180.

18 See H.J. Oosting, Soendasch-Nederduitsch woordenboek (Batavia: Ogilvie, 1879), p. 708.

${ }_{19}$ G.F. Pijper, "De vrouw en de moskee," in his Fragmenta Islamica, (Leiden: Brill, 1934), p. 29

${ }^{20}$ Hoesein Djajaningrat, Atjeh-Netherland Wordenbook, II (1934), pp. 723-724.

${ }^{21}$ Poerwadarmita, Kamus Besar Bahasa Indonesia, p. 596.

22 See Wilkinson, R.J., Malay-English Dictionary, II (Mytilene: Salapaulos and Kinderlis, 1932), p. 554.

23 Gerard Moussay, Dictionnaire Minangkabau-Indonesian-Francais, II (Paris: 1995), p. 1176

24 Jones Russell, Loan-words in Indonesian and Malay (Leiden: KITLV Press, 2007) p. 120; Oosting, Soendasch-Nederduitsch, p. 708.

25 See Ibn al-Mandzur, Lisan al-Árab, V. III (Beirut: Dar Lisan al-Árab, n.d.), p. 184.

26 Poerwadarmita, Kamus Besar Bahasa Indonesia, p. 596.
} 


\section{Kekudung}

Kekudung or kudung is both loose headscarf which still exposed the hair and neck, and tied which only showed the face. According to Pijper, in the 1930s, the people in Batavia (Jakarta) and some Malay areas called a Muslim woman's headscarf as kudungan or krudungan; whereas the Javanese called it kudung and the Sundanese called it tiyung or kukudung:27 some other Malay people also call it telekung:28 Minagkabau Muslim call it tikuluak. ${ }^{29}$ and tilakuang. ${ }^{30}$ In the 1900s, according to Snouck Hurgronje, the Achehnese called women's headscarf as ija tob ulee (literally means "a cloth that covers head); ${ }^{31}$ and sometimes an Achehnese shawl, ija sawa, 32 was also used to cover women's head. Those terms were often used as a translation of khimar, used by Q 24: $31 . .^{33}$ The general style of headscarf at that time was like a headscarf that does not cover woman's head and hair completely and the front neck and ears remained exposed; In the early twentieth century, few Muslim women wore it as a daily cloth used in all occasions and most of them usually wore it when they attended Islamic celebrations such as Maulid Nabi and Isra Mi'raj in mosques and when they recited and studied the Quran or other Islamic subjects (ngaji). ${ }^{34}$

There is a special term for kerudung used by Muslim women who has performed pilgrimage to Mecca; it is called Mibram or mibramah which is defined as a (stiff pleated) white cloth worn by women haji. ${ }^{35}$ The term is also loanword from Arabic mabrama (something not to be collided) and it was loaned from the Hijazi townswomen tradition; it was like a traditional rectangular headgear. It was generally known that

\footnotetext{
27 Pijper, "De vrouw en de moskee," p. 31.

28 Safarwan, Kamus Besar Bahasa Melayu, p. 1931.

29 Nurlela Adnan, Ermitati and Rosnida M. Nur (eds). Kamus Bahasa IndonesiaMinangkabau (Jakarta: Balai Pustaka, 2001), p. 341.

${ }^{30}$ Moussay, Dictionnaire Minangkabau, p. 1176.

${ }^{31}$ Snouck Hurgronje, The Achehnese, I (Leiden: BRILL, 1906), p. 25.

32 See Hoesein Djajaningrat, Atjeb-Netherland Wordenbook, I (1934), p. 608.

33 In linguistics, such terms are called loanshift which means is a kind of word loaning that shows complete morphemic substitution without showing any character of the importation process. See Hsia, The Influence of English, p. 24.

34 Pijper, "De vrouw en de moskee," p. 31.

35 F.S. Eringa, Soendaas-Nederlands woordenboek (Dordrecht: Foris, 1984), p. 501.
} 
most Indonesian pilgrims usually imitated the Arab dress when returning to their homelands. It was intended to distinguish themselves from those who had not performed pilgrimage to Mecca and also mostly to indicate their commitment to perform their belief more faithfully. ${ }^{36}$

This term is actually utilized only by the Sundanese hajji; when the adjunct-advisor of the Dutch government, Pijper, observed West Java in which Sundanese people live, the term has been utilized in the 1930s. ${ }^{37}$ However, as a Sundanese and live within the Sundanese community, until now (2009) I never hear this term before; it is apparently no longer used because the popularity of headscarf makes not only hajjah (woman haji) but also others to wear it. ${ }^{38}$

\section{Propagating Headscarf and Face Veiling: Kekudung and Berguk The Propagation of headscarf}

The fact that many Muslim women did not cover their heads encouraged some reformist Muslims to actively propagate and state that headscarf is obligation for Muslim women. In order to make women adopt veiling, Ahmad Dahlan, the founder of Muhammadiyah, since the 1910s had propagated veiling gradually to Muslim women in Kauman, Yogyakarta. ${ }^{39}$ He began suggesting them to cut their ati2 (related to the wudu problem) and made them dijambuli. They kept doing it although many people mocked them. Then he asked them to wear kudung sarung from Bombay; the first kudung was made from used sorban puteran. This also invited others who disliked it to mock; for instance they said, Lunga nang lor plengkung, bisa jadi kaji (go to the north

\footnotetext{
36 Snouck Hurgronje, Mekek in the Latter Part of the 19th Century, (Leiden: Brill, 1931), p. 243.

${ }^{37}$ see Pijper, "De vrouw en de moskee," p. 20.

${ }^{38}$ It is usually worn along with other pieces of cloth: the triangular Shambar, and the square Mudawwarab; see Heather Colyer Ross, The art of Arabian costume: a Saudi Arabian profile (Fribourg: Arabesque, 1981), pp. 90-1.

39 The earliest propagation on the obligation of headscarf presumably was written by Sayyid Uthmân in October 1899; see Sayyid 'Uthmaæ, Lima Su'al Didalam Peribal Memakai Kerudung (Batavia: Self-published, 1899). According to Nico Kaptein, the book contains fatwa arguing that women should cover their heads when they would leave her house and it is more in line with discussions occurring in the Middle East; see Kaptein, "Southeast Asian Debates," p. 191.
} 
direction of the plengkung, ${ }^{40}$ you will become haji). ${ }^{41}$ The origin of this saying is that at that time only women who wore headscarf as daily dress were those who had performed hajj. Ahmad Dahlan asked them not to show their jewelries and to wear dress that did not show up their feminine charms. Even though he encouraged women to participate in women emancipation movement, he also intensified the sexual segregation between men and women. That is why he encouraged women to become doctors, so that women would not need to reveal their private parts of body to male doctors. ${ }^{42}$

Figure 2: One of the advertisements of women headscarf displayed by a Muhammadiyah weekly magazine, Adil.

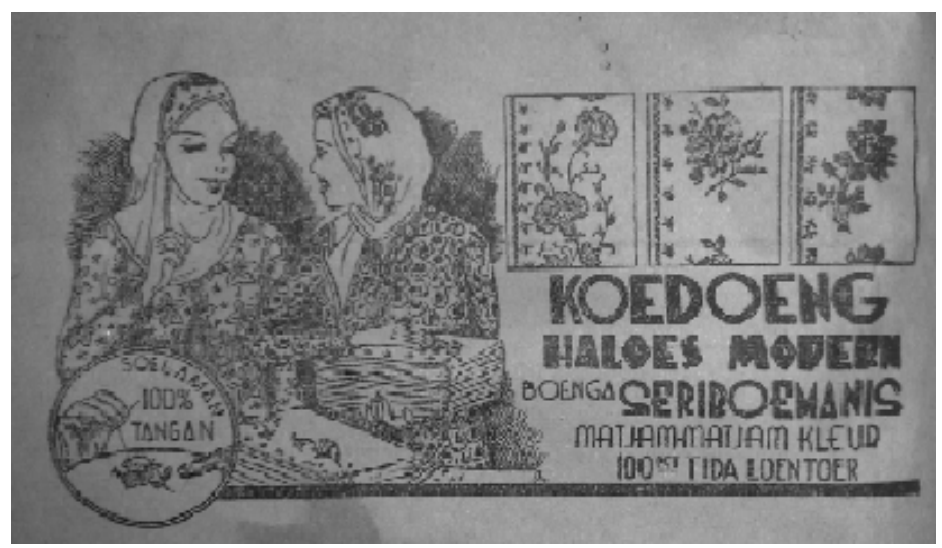

In the 1920s, one of the ifluential ulama of Muhammadiyah, Haji Abdul Karim Amrullah, wrote a detailed book with more than 200 pages, Cermin Terus, ${ }^{43}$ discussing his opinions regarding Muslim women based on his interpretations of the Quran and and hadith. He described some measurements of womens' dress according to hadith

40 Ahmad Dahlan's house was located on the south of the intersection of Kauman street which every its sudut jalannya had a gate with plengkung decoration.

${ }^{41}$ His message was Hantu tidak menjilat, setan tidak suka, yang tidak tahan busuk lidahnya; see Salichin Salam, K.H. Abmad Dablan: Reformer Indonesia (Jakarta: Jajamurni, 1963), pp. $52-5$.

42 See Peacock, Purifying the faith: the Muhammadiyah Movement in Indonesian Islam (California: University of Minnesota, 1978), p. 38.

${ }^{43}$ Unfortunately, I can't find the book; the information in the following paragraphs is documented in his biography book, Ayabku, written by his son, Hamka. 
and ulama's opinions. Then he critisized a traditional women dress of kebaya pendek (short kebaya) that sometimes exposed cleavages. He stated his arguements in angry tones, telling that kebaya pendek is "pakaian perempuan lacur" (the dress of a whore). ${ }^{44}$

This book invited many critics and even triggered other related debates. His own son, Hamka, acknowledge that his father's arguements on dress was narrow minded and called his father's ideas as the common idea in the medieval Islam. In addition, the book was criticized by his own student, Rasuna Said who wrote in a daily newspaper, Mustika Yogya. Then thourgh a letter, Nur Sutan Iskandar from Jakarta critisized him, stating that it was inappropiate to consider kebaya pendek as haram (religiously forbidden). Iskandar argued that Amrullah's fatwa should consider a spesific place, not generalizing all places; his fatwa might fit only in Minangkabau where short kebaya dress was scarsely found, because the people in West Sumatra used to wear baju berkurung panjang (long wide dress, like a gown); but Java was not the case, since most Muslim women still wore short kebaya. ${ }^{45}$ Unable to accept Iskandar's arguements, Amrullah wrote another book, Pelita I; He answered and even his opinions on kebaya pendek became much more negative. For the second time, he received a long letter from Rajo Pelawan, critisizing his arguments in Cermin Terus. Pelawan argued if Amrullah's opinions in the book were true, Islam only gave few rights to women whereas men get too many rights and very few obligations. Since Pelawan's nasty tone in the letter made Amrullah much more angry, he replied Pelawan's arguements on the same tone, in his book Pelita II. The debates did not stop, even this last book invited other hot debates in which Amrullah accused Pelawan to have made blasphemy on the prophet Muhammad. This accusation brought him into polemics with adat leaders. ${ }^{46}$

Another reformist organisation, Al-Irsyad in its congress in Pekalongan, Central Java, had discussed women issues, entitled " Orang Perempuan dalam Islam Menurut Pandangan Golongan al-Irsyad" ( Women in Islam from al-Irsyad Perspective). One of the results of the congress suggested its women members to cover their heads and bodies except

\footnotetext{
${ }^{44}$ See, Hamka, Ayahku, (Jakarta: Umminda, 1982), pp. 193-4.

45 Ibid., p. 194.

46 Ibid., pp. 194-9.
} 
face and palm and also supported them to keep away from sex-mixed gatherings. ${ }^{47}$

The most active and opensive reformist organisation that propagated the obligation of headcover was Persis. The most influential leader of Persis, Ahmad Hassan, wrote his first propagation on the obligation of headscarf for Muslim women in 1932.48 Since the founders of Persis were inspired by al-Manar, their initiative to propagate the obligation of headscarf was presumably influenced by Rashid ridha's book, published by al-Manar, published in 1932. The

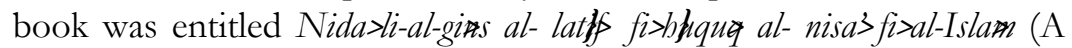
Call to the Fair Sex on Women's Rights in Islam). The book spread in Indonesia and quoted by Indonesian modernist Muslim scholars when discussing Muslim women's dress. ${ }^{49}$

Moreover, female members of Persis wore a different style of wearing headscarf, the tight veil. They completely covered their head and showed only face; the headscarf did not expose any hair, neck, ears and parts of chest which were still exposed by other headscarf. ${ }^{50}$ They wore it not only when they performed religious rituals or activities but they wore it as a daily cloth. This new custom, accompanied by the newly held conviction that women who did not cover her head would enter hell, invited debates and even a physical clash among opposing sides.

In 1934, a Muslim preacher propagated that women who ignored to cover their head would enter hell. This speach then spread and caused some anxieties among people, including the head of Bandung district. This public official could not help but to publicly express his opinion on the issue. He stated that any cheap headscarf could help the person who wore it to enter heaven. Not long after this provocative speech, an incident against a female member of Persis occured in Pameungpeuk, West Java as some people threw stones to

\footnotetext{
47 Aliran Baroe, no. 36 (July 1941), pp. 10-11.

48 A. Hassan, "Dari Hal Koedoeng Perempoean, Pergaoelannya, dan lain-lainja," Pembela Islam, 43 (February 1932), pp. 27-9.

49 See Aliran Baroe, no. 34 (May 1941).

50 L. Marcoes-Natsir, "Profil Organisasi Wanita Islam Indonesia: Studi Kasus PERSISTRI," in L. Marcoes-Natsir \& J.H. Meuleman (eds), Wanita Islam Indonesia dalam Kajian Tekstual dan Kontekstual (Jakarta: INIS, Kumpulan Makalah Seminar Seri INIS, XVII, 1993), p. 100.
} 
her because she wore a different style of headscarf, thight veil. No one admitted to be responsible for that violence, but it was apparently because of the provocative speech from the head of Bandung district. ${ }^{1}$

\section{The Propagation of Berguk}

Beside the ongoing debate on headscarf, in March 1940 emerged a new radical movement in Solo initiated by two alawiyyin, Idrus alMasyhur and Ali bin Yahya. They intended to ask alawiyyin's wives to wear berguk (Arabic: burqa). ${ }^{52}$ In March 5, 1940 sixty people of Alawiyyin gathered to discuss berguk. The leader of the meeting, Idrus al-Masyhur, said that Arab people whose population was about 70 thousands were no longer concerned in Islamic teachings and many Arab people also kept away from Islam. Islam was degraded because of the ignorance of its followers. Their forefathers were good people because they paid attention to bijab and berguk; but now many people were insane, so that their women were easily seen unveiled in streets. ${ }^{53}$

Two meetings that had been held in Bin Basri's house resulted in a conclusion that Muslim women then had disobeyed sharia. They argued that the modernization should not be applied in a tabarrij (exposure) way; many people cried because their women wore halfnude clothes which was caused by tabarruj. One of the members, Ahmad bin Abdullah Assegaf, stated that because women were away from moral values, alawiyyin should give them bijab and urged them to wear berguk. Ali bin Yahya claimed that many alawiyyin men, youth and women were immoral. Alawiyyin had betrayed the prophet and if the prophet was still alive, he would be extremely ashamed. Many Muslim organizations turned away from religion and propagated tabarrij. As Alawiyyin, they had to be careful of such organizations. Segaf alHabsyi added, because the people of Solo had initiated the movement of berguk, history would write it with the golden ink. ${ }^{54}$ Because many

51 See A. Hassan, Soal-jawab Tentang Berbagai Masalah Agama (Bandung: C.V. Diponegoro, 1977), pp. 191-2

52 Al-Masyhur was originally from Surabaya. After his newspapers, Hadramaut Courant, stopped issuing, al-Masyhur moved to Solo, escaping from social movement in Arab communities in Surabaya and trying to begin merger business in batik with his colleague, Ali bin Yahya who got married to a rich businessman's daughter. Aliran Baroe, no. 20 (March 1940), p. 4.

53 Ibid., p. 13.

${ }^{54}$ Ibid. 
wives of Alawiyyin walked on streets with perfumes, al-Habsy recommended the audience to force their wives to wear berguk as it was wore by Arab Muslim women in the Middle Eastern countries.

In the same tone, Abdul Kadir al-Jufri said that many Arab Muslim Women were no longer ashamed with Arab men. They walked on the street without headscarf. Such situation was dangerous and it was obliged to men to order their women to wear berguk. Other influential Alawiyyin, Omar Abdurrahman Assegaf, stated that because of the Arab passion (ghirah Arabiyyah) and honour (sharaf), Alawiyyin had to make women to wear it. He asserted that there was no longer any difference between Arab women and Javanese women. So, Arab women must wear berguk in order to differentiate between Arab women and Javanese women." ${ }^{55}$

Since there was not any member of the meeting who raise objections on the importance of berguk, the agreements on the campaign were signed as the following,

"The meeting which has been held in February 1940 in Salim bin Basrie's house concluded that berguk is a religious obligation for women. Another meeting held in the same house on March 3, 1940 decided that "every Alawiyyin man must oblige his wife and women under his control to wear berguk; he who disobey this decision would be reminded three times and if he still ignores, he will be excommunicated."

After gaining the agreement, the leader of the committee of berguk, Idrus Masyhur, collected donation to produce berguk as many as he could and gave them for free to poor women who wanted to wear it. The committee decided to send al-Masyhur to Magelang, Central Java, and then to Surabaya, East Java, to promote wearing berguk.

The city of Solo which had been a peaceful city for thirty years and free from polemics and fights was then destructed by this berguk. The committee of berguk ordered all alawiyyin's wives to had worn berguk by March the $25^{\text {th }} 1940$, but when the day came the order was not fully fulfilled. The issue of berguk not only spread in Solo but also steadily spread to Surabaya and became hot issue in mass media and even reached to Bali. A reader of Aliran Baroe magazine wrote a letter to the editor in an anecdotal tone saying that he, along with some Balinese

55 Ibid., p. 13. 
people, was frightened if the movement of berguk was successful in Solo, American tourists would no longer visit Bali, because there was a new interesting scene and phenomenon in Solo where the Arab wives wore berguk.

In responding the campaign by their brothers, Arab wives rebelled and rejected the idea of wearing berguk. They stated that it was better to die or got killed than to be an object of 'show' by being forced to wear berguk. Moreover, there was an Arab woman who would ask a divorce if she was still forced to wear it. In June 1940, an Arab woman in Solo was divorced after ten years of marriage because she did not wear berguk when she visited her neighbor to express condolence following the death of a family member. Moreover, along with her eight children, she was expelled from her house by her husband, Segaf bin Basri Assegaf. For the same reason, she refused to wear it because she did want to be the object of mocking and laugh. ${ }^{56}$ In another incident, when an Arab named Zien bin Husein Assegaf was sick many people visited him. Among the visitors was a woman who did not wear berguk, whereas his husband was a loyal supporter of the campaign. Knowing that she did not wear it, the husband directly went to the house of the sick and a fight occurred between the husband and wife in front of the sick person. Because of this, many women who witnessed the incident cried and cursed the campaign. ${ }^{57}$

These incidents opposing the berguk campaign made people angry and blamed the berguk campaign initiators, including Masyhur bin Yahya. Once Masyhur visited Surabaya, some people laughed at him because of his ideas of berguk. More shockingly, when he was in the front of a shop in Surabaya some young Arab football players in a bus that passed by him insulted him by yelling " berguk, berguk." 58 These incidents presumably also occurred in other areas.

At the end, the berguk campaign failed to attract followers in Solo and Surabaya. One of the main initiators of berguk, Ali bin Yahya, asked Bin Jindan to help him promoting berguk to women in Solo. However, instead of promoting it, Bin Jindan refused it, stating that he preferred to dig a grave to burry all kinds of berguk in Solo, so that berguk would never appear because it had caused embarrassing

\footnotetext{
56 Aliran Baroe, no. 23 (June 1940), p. 12.

57 Ibid., p. 13.

58 Aliran Baroe, no. 21 (April 1940), p. 19.
} 
problems. ${ }^{59}$ Humiliated by this failure, initiators of berguk campaign escaped to Betawi (now Jakarta). ${ }^{60}$

\section{Debates and Tensions: Nationalists and Reformists on Veiling}

The issue of veiling became a contentious debate in mass media from 1939 to 1941 and invited tension among them. The debate occured between reformist and traditional Muslims. There were at least three publications involved in the debate, Aliran Baru which was affiliated to the nationalit Muslims and al-Fatch and al-Lisan which belonged to the Modernist Muslims.

\section{Muslim Nationalists}

Indonesian nationalists who got involved in the debate of veiling were of Arab origin. They were usually of mixed origin with Arabic father and Indonesian mothers. They spoke Indonesian as their mother tongue, sometimes having no knowledge of Arabic. They adopted Indonesian customs, especially among non-sayyid communities ${ }^{61}$ In the early twentieth century their identity as an Indonesian was strengthened in 1934 by their commitment to widely accept Sumpab Pemuda Indonesia (the oath of Indonesian youth) that led to the establishment of Partai Arab Indonesia (Indonesian Arab Party). ${ }^{62}$ The first leader of PAI, A.R. Baswedan, once told to the mix-origin Arabs that their land was not Hadhramaut (Yemen) but Indonesia. ${ }^{63}$ It can be said that "the reforms of institutions whithin the Arab community tended to spill over the Indonesian community." 64

\footnotetext{
59 Aliran Baroe, no. 23 (June 1940), p. 12

60 Aliran Baroe, no. 20 (March 1940), p. 19

${ }^{61}$ Sayyid (syarifah for women) is believed to be descendants of the prophet Muhammad through his daughter Fatima.
}

62 P.A.I was founded by the initiative of AR Baswedan in 1934 and was intended to actively participate in political activities and nationalism movement against Dutch collonialisms. Baswedan became vice minister of Information in 1945. Although this organisation was modern, some of its members had certain Islamic views were much linked with the traditional Islam which preserved religious traditions such as tablil and talqin.

${ }^{63}$ See Hamka, "Mengabadikan Sebuah Pertemuan Dengan Sahabat," Panji Masyarakat, no. 25 , p. 16.

${ }^{64}$ See Noer, the Modernist Muslim Movement, p. 56. 
There are two main magazines published by P.A.I to spread its political and religious perspective, Aliran Baru and Insyaf. Concerning the issue of veiling, through Aliran Baru P.A.I responded by writing at least sixteen articles, entitled Soal Kudung (the problem of headscarf). The articles were placed in a special column provided for religious issues, called Ruang Agama (the space of religion). They were written by its editor Husein Bafaqieh and issued between December 1939 and April 1941. Because of readers request, the articles then were published under the title Soal Kekudung (the treatise on Headscarf). ${ }^{65}$ Although the articles were written by a single person, but they were claimed to be published on behalf of the organization, not merely personal statement.

\section{Muslim Reformists}

Al-Fatch magazine belonged to Aisyiah, a Muslim women organisation which is affiliated to the biggest reformist organisation, Muhammadiyah. As far as I know, al-Fatch responded to Aliran Baru only twice with the opinion written by Siti Zubaidah. Even though Zubaidah's arguments were countered back by Aliran Baru magazine, she apparently did not react further. It can be understood since Muhammadiyah's policy was to avoid debates and more concerned in social prosperity through education, health centers and charity organisations. ${ }^{66}$

Al-lisan magazined belonged to Persis's publications which financially much depended on Ahmad Hassan. It gained its circulation until 2,000 copies throughout Indonesia. It readers particularly came from other Muslim reformist organisation, Muhammadiyah and alIrsyad. ${ }^{67}$ Besides, Persis had abundant publications to promote its perspective on several religious issues. Moreover, Ahmad Hassan was a productive. ${ }^{68}$ The article of al-Lisan on headscarf were written as a response to the articles of Aliran Baru magazine. Later, the articles were

\footnotetext{
${ }^{65}$ See H. Bafagieh, Soal Kekudung (n.p.: Penyiaran Ilmu, 1941).

66 One of Muhammadiah's mottoes was "Sedikit bicara, banyak bekerja" (speak little, do much); they did criticize the tradition but they tried to be tolerant in propagating their opinions and kept away from polemics with other organizations because, according to their experience, the polemics only would make them difficult to get their goals; see Pijper, Beberapa Studi Tentang Sejarah Islam, pp. 108-114.

${ }^{67}$ Noer, the Modernist Muslim Movement, p. 91.

${ }^{68}$ Pijper, Beberapa Studi Tentang Sejarah Islam, p. 129.
} 
published by Persis in a book entitled Risalah Kudung (the treatise on headscarf).

\section{Debates and Tensions}

The debate started in November 1939 for two reasons: a photograph describing an Egyptian Muslim woman with bare head and an editor statement concerning the obligation of headscarf for female members of Partai Arab Indonesia (P.A.I.). A reader of Aliran Baroe magazine asked Charraat, one of the editors, concerning headscarf after knowing the fact that many wives of P.A.I members did not wear headscarf. Responding to the question, Charraat personally suggested that it was better for P.A.I not to be involved in this issue and should give its members the freedom to choose. At that time, P.A.I itself officially had not responded to the issue yet. ${ }^{69}$

Figure 2: Image attached at the women section of Aliran Baroe magazine.

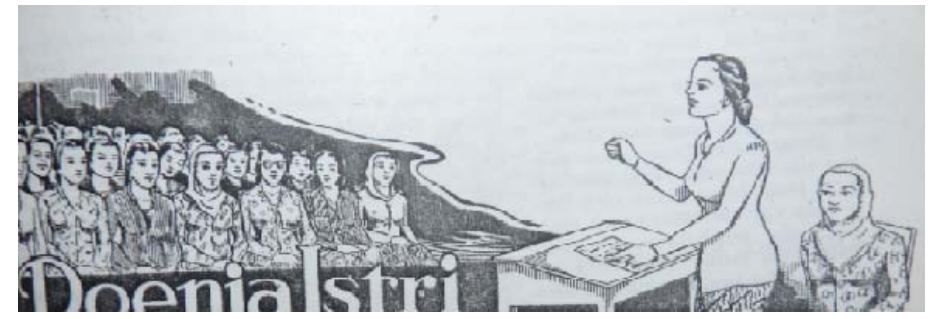

Charraat's statement invited Siti Zoebaidah from Al-Fatch magazine to write an article criticizing the policy of P.A.I on wearing headscarf. Firstly, he criticized the photograph of an Egyptian Muslim woman, Abkaar Assegaf, wearing Western dress and exposing her hair. She argued that the woman had disobeyed the ethics of modesty in Islam; moreover her image, said P.A.I, was a commonplace in Egypt. She was troubled if Indonesian Muslim women adopted this tradition, the thunder would stroke earth. Secondly, she argued that wearing headscarf was obliged by Islam for every Muslim woman. She wondered why P.A.I. Allowed Muslim women not to wear headscarf while Indonesian Muslim women were actively awakening the awareness to wear it. ${ }^{70}$

69 Aliran Baroe, no. 16, (November 1939), p. 32.

70 Aliran Baroe, no. 17 (November 1939), p. 15. 
In the same month, December 1939, on of the editors of Aliran Baru, A. Bafagieh, replied Zubaidah's critics. He did not agree that the woman in the photograph disobeyed the ethics of Islamic modesty and stated that her opinion was narrow. Concerning the issue of headscarf, he argued that it was debatable issue, masalab kbilafiah. There was not any clear nash (stipulation) from the Quran and hadith that obliged women to wear headscarf. The most quoted verses to oblige headscarf were multi interpretable. He noted that most Muslim women in the Muslim countries, such as Egypt, Syria, Palestine, Iraq, Lebanon, Iran, Afghanistan and even Turkey, wore western clothes and uncovered their heads. Having said that, it was not a problem for them and no one accused them of having disobeyed the ethics of Islamic modesty. ${ }^{71}$ He considered the issue of veiling as trivial issue, not as crucial as Zubaidah assumed. Her accusation was premature and has no foundation. Even so, he appreciated her campaign to wear headscarf but he stayed in neutral attitude, allowing women to wear headscarf as a tradition or as religious obligation. ${ }^{72}$

Charraat's statement also invited another reader to re-question the reason of P.A.I which considered wearing headscarf was a matter of choice, provided that P.A.I. was an Islam based-organization. That reader specifically emphasized that Islamic laws exactly denounced the women who uncovered their head. Again, A. Bafagieh answered that the issue of headscarf was debatable, so-called masalah khilafiyah, since many ulama disagreead on it. The issue of veiling led the editor to explain the parts of woman body that must be covered, so-called aurat. Then he explained that ulama had disagreed on aurat. Some said that it was whole body, some stated except face and palm, and some others argued from navel to knee, as practiced by many Egyptian Muslim women. Finally he argued that Islam did not regulate on how Muslim women should dress because there was not a consensus on Muslim dress in Islam. ${ }^{73}$

Zubaidah was surprised with Bafaqieh's opinion who state that Islam did not regulate women dress code. In reply, she wrote an article concerning the obligation of headscarf in the same magazine, relying on the Quran and hadith. As the final statement, Zubaidah argued that

\footnotetext{
${ }^{71}$ Ibid., p. 16.

72 Ibid., p. 17.

73 Aliran Baroe, no. 17 (December 1939), p. 11.
} 
the obligation of veiling was not debatable but it was fixed in the Quran and hadith; she concluded

In regard with headscarf, it is no longer a difficult and debatable issue for us, Aisyiah organization. However, in P.A.I it is still debatable and became masalah kbilafiyah. It is far beyond our imagination. We have just heard that it is a part of masalah khilafiyah and debatable issues. More shockingly, it is said that in Egypt there is ulama who argues that women's aurat is from navel to knee, just like men's aurat. $^{74}$

Encouraged by curious readers and normative debates with Zubaidah, on behalf of the organization, P.A.I publicly announced its policy of being neutral on the issue of veiling on January 1940, as suggested by Charraat in December 1939.75 Having started the controversy, P.A.I. felt responsible to give adequate information on the issue and decided to write series of articles concerning the issue. P.A.I stated that they would be in a neutral side, explaining and discussing all arguments from both the pros and the cons.

Trying to be neutral, P.A.I was involved in contentious debate with another reformist Muslim organization, Persis. Among the influential leaders of Persis who was involved in defending the obligation of headscarf was A. Hassan (1887-1958). ${ }^{76}$ Hassan was involved in debates on various Islamic issues, including headscarf, with Aliran Baroe or P.A.I. Hassan considered headscarf as an important issue to prevent negative impacts and influences of Western ideas to Indonesia.

\footnotetext{
${ }^{74}$ The original texts are, "Kalau tentang koedoeng, bagi kami kita kaum Aisyiah bukan lagi menjadi masyalah yang sulit dan bertikaian faham; akan tetapi rupanya dalam kalangan P.A.I. masih jadi peroendingan musykil dan sebagai masalah khilafiah. Hal ini jauh diluar dogaan kita. Baru sekali ini saja dengar bahasa kudung termasuk masalah khilafiah dan pertiakaian faham. Lebih heran lagi, konon di Mesir ada ulama berfaham bahwa aurat perempuan hanya sejak dari pusat hingga lutut seperti laki-laki" ; this text was quoted by Aliran Baroe, "Aliran Baru Kontra Siti Zubaidah,” no. 17 (January 1940), p. 15.

75 Aliran Baroe, no. 18 (January 1940), p. 13.

${ }^{76}$ According to Fiederspiel, the influence of A. Hasan's ideas was so strong and in the later periods it can be said that PERSIS was identical to A. Hasan; his ideas contributed to the shape and the character of PERSIS and at the same time put it in the modern Muslim organisations; further information on A. Hassan and his ideas, see Akh. Minhaji, Ahmad Hassan and Islamic Legal Reform in Indonesia [1887-1958] (Yogyakarta: Kurnia Kalam Semesta, 2001).
} 
He often mentioned, for instance, Eropa (Europe) as the representative of Western society when discussing and criticizing the social role of women. According to him, women of Western society had gone too far, exceeding their nature as women. ${ }^{77}$

Hassan argued that the problem of women's dress in Indonesia was one of the contagious diseases spread by Western thoughts. Among Indonesian Muslims who had been influenced by Western ideas, according to him, was Aliran Baroe. He stated that Aliran Baroe had manipulated Islamic teachings to support its liberal ideas. Aliran Baroe often quoted some anonymous Muslim scholars of Egypt, ${ }^{78}$ a country where feminist movement became popular at that time under its president Huda Sha'rawi Pasha who founded it in 1925. Accordingly, he often criticized Aliran Baru with nasty overtones and even called it as Majalla Galilul Iman (a magazine with shallow conviction) ${ }^{79}$

In addition, Hassan doubted P.A.I's neutral position on the issue of veiling. He questioned that if P.A.I stated that wearing headscarf was a matter of choice, why it forbade strictly the berguk campaign which was initiated by its member, Mansyur ibn Yahya in Solo. Responding to this statement, P.A.I considered the campaign as tendentious. P.A.I argued that Mansyur had no sincere religious motivation. The provision saying that whoever did not ask his wife to wear berguk would be excommunicated is irrational. ${ }^{80}$

In later periods, some members of P.A.I, as quoted by Aliran Baroe, argued that the use of headscarf was recommended, instead of obliged. Thus, Muslim women who did not cover their heads were not violating Islamic teachings, but they should not be the object of condemnation. On the contrary, Hassan writing in Persis' magazine, al-Lisan, insisted that the obligation of headscarf was fixed in the Quran and hadith. The both sides drew their different opinions on the same verse of the Quran, 24:31. Aliran Baroe argued that to understand the verse, it must be viewed in the context of the preceding (Q 24: 29) and following ( $Q$ 24:32) verses. The preceding verse was about the rules of entering

\footnotetext{
77 Ibid., p. 200.

78 A. Hassan, Wanita Islam: Jilbab, di Podium, Jabatan Tangan (Bangil: Percetakan Persatuan, 1989), p. 18.

79 Aliran Baroe, no. 18 (December 1939), p. 14.

80 Aliran Baroe, no. 23 (May 1940), p. 7.
} 
others' houses which was recommended to ask permission, not obligatory, whereas the following verse was about the importance to facilitate single men and women to get married which was also recommended. Aliran Baroe concluded that if the preceding and following verse were recommended, the rule for the verse between them was recommended not obligatory. This conclusion was said to be supported by the fact that those verses were connected each other by the conjunction $w a$ (and); and the rules which were connected by that conjunction had the same force. Based on this context, Aliran Baroe concluded that the rule of headscarf was not obligatory but recommended. ${ }^{81}$

Hassan completely refused such line of reasoning and even he accused Aliran Baroe to have manipulated the verses to fulfill his own desire. He rejected such argument based on two reasons; first, it was noteworthy that the verses Q 24: 27, 28 and 29 were concerned on the issue of being a good guest, whereas Q 24:30 is not started by the conjunction wa which may indicate that there was no any relation with the preceded verse. Then comes Q 24:31 which is concerned on women's dress and started by the conjunction. The two verses Q 24: 30 and 31 were addressed to Muhammad and completely disconnected from the following ones. The following verse Q 24: 32, started by the conjunction, was addressed to all believers in general. Based on this line, Hassan rejected Aliran Baroe's reasoning which simply based their argument on the conjunction connecting all verses. Second, it was not true to conclude that every subject connected by the conjunction must have the similar injunction. For instance, Q 6:141 states "Eat of their fruit in their season, and (wa, Yusuf Ali translates it into "but") render the dues that are proper on the day of harvest is gathered." Even though two subjects, eat, and charity, in this verse are connected by the conjunction, but they do not have the same injunction; the first is permitted (mubal and the second is obliged (wajib). Hassan argued that the rule of wearing headscarf was expressed in imperative form (amr) which basically imply obligatory, as stated in the Islamic legal theory $(u s u \diamond f i q b)$ in the following principle: al-asld fi al-amr lil-wujul (the imperative originally indicates obligation). This obligatory injunction would shift to become recommended and permitted, if there was an indication (qarima). Concerning headscarf, Hassan did not find any

81 Al-Lisan, p. 11. 
indication which shifted headscarf from its original obligatory rule. This fact, according to Hassan, indicated that Aliran Baroe did not understand how to use Arabic grammar and even how to exercise legal interpretation from the Quran (instinbat 82

Another argument posed by Aliran Baroe was the contextual reason of the verse Q 33:59. The wearing of the veil in this verse at that time was intended to differentiate between free Muslim women and slave ones. Some men often disturbed slave women when they went out home. Thus, free Muslim women were ordered to wear veil in order to get easily identified as free women and kept away from those irresponsible men. Accordingly, Aliran Baroe argued that the essence of the verse was that veiling was to differentiate between good women and bad ones which might be different from time to time and from place to place. It was supported, according to Aliran Baroe, by the fact that Imam Syafi'I had two set of different opinions on some issues, socalled qawl al-qadim (old opinion) and qawl al-jadi (new opinion) which were resulted from his experience in different time and place.

Such argument was also rejected by Hassan, stating that it represented nothing more than a justification of their ignorance about the obligation of veiling. He considered such argument as a dangerous if it was applied to other Islamic issues. He argued, for instance, if such argument was applied in praying, we would say since the purpose of praying five times was for refraining Muslim from performing shameful and unjust deeds (inna al shla tanha 'an al-fakhsha wa almunkar), good Muslims needed not to perform praying if they had always done good deeds. Moreover, Hassan gave an anecdote that the leaders of Aliran Baroe probably would say "if we have become good human, we no longer need religion because the essence of religion is to make people good".

The third argument of Aliran Baroe was that the hadith of Asma supporting the obligatory veiling was $d h a^{i}$ if (weak). Moreover, the words la faslah \}(lit: not appropriate) in the hadith also could not mean prohibition. Although Hassan acknowledged that the hadith was dha if such argument was also refused by Hassan. He argued that Muslim scholars did not use the $b$ ddi as a fundamental reason in justifying the obligation of veiling but as a supportive indication in understanding other stronger texts (the Quran) on the veiling. He also did not agree if

82 Al-Lisan, pp. 12-4. 
the word la faslihb could not mean prohibition. For instance, the world

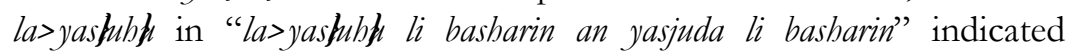
prohibition so that the saying can be translated "it is forbidden for human to worship other humans."

Hassan was very keen on debating and polemics in dealing with Indonesian Muslim traditions. In the case of headscarf he stood up in the front line and publicly stated that he invited P.A.I to debate on this issue in November 1940. Husain Bakri, one of the editor of Aliran Baroe, felt was disappointed with Hassan's decision to debate, wondering whether his pen was broken. However, he welcomed humbly to the call. ${ }^{83}$ Husain Bakri's agreement to perform debate with A. Hassan eventually did not come into reality. He preferred to write other five articles in Aliran Baroe until April 1941; the articles were then published in a book in October 1941. In response, in the same year alLisan then published Risalah Kudung. In the end of this book, Persis once again challenged P.A.I to organize a meeting between them to discuss the issue, as we can see in the following, ${ }^{84}$

Because this issue (veiling) is important and we might still have other arguments that could be explained further, we expect that the group of Aliran Baroe and its Syaikhul Islam along with its mufti and supporters, including Hoesein Bakri from Pekalongan, are disposed to have a meeting with us. The arrangement of that meeting is up to Aliran Baroe. In that (meeting) we can discuss everything and the results of the meeting could be printed and distributed for free or otherwise. We do not mind if you consider it as the call for scratching, debating, fighting and etc. The most important is that the meeting is succesful. If you think that you are in the right side, do not be afraid to meet (us) in a wellorganized place, accompanied by jurists and their members. ${ }^{85}$

\footnotetext{
${ }^{83}$ see Aliran Baroe, no. 28 (November 1940), p. 16.

${ }^{84}$ Husain suggested A. Hassan to rephrase the term 'debate' with 'mau mengaji' (want to study), indicating that he respected Hassan as konwlegeable ulama and wanted to study from him. A few months before Hassan invited debate, Husain had told him that he wanted to become his student. See Ibid., p. 68.

85 The Indonesian version is "Oleh sebab masalab ini sangat penting dan masib ada lagi alasanalasan yang boleh dikemukakan dari sana dan sini, maka kami harap supaya golongan Aliran Baru dan syaikhul Islamnya serta Muftinya sampai ke ekor-ekornya, inklusif tuan Hoesein Bakri, Pekalongan, suka bertemu dengan kami dalam satu ertemuan yang syarat-syaratnya boleh fihak
} 
An open debate between both sides eventually did not happen because of the political condition. At that time, the Japanese invaded Indonesia. The debates on media also did not continue; the magazine of al-Lisan, financially depended on Hassan, stopped issuing. ${ }^{86}$ The rest publication of Persis also discontinued from 1942 to 1945 due to the tight censorship from Japanese occupation officials. ${ }^{87}$ Moreover, Persis' school in Bangil, East Java and its other activities stopped its activities because of the Japanese ban. ${ }^{8}$

\section{Conclusion}

From the aforementioned description, it is clear that the propagation and the adoption of veiling in the early twentieth century were indirectly inspired influenced by Islamic reforms in the Middle East, especially Egypt. The passion of Islamic reform led Indonesian Muslim scholars to rethink their own traditions, including Islamic attire, and to rehabilitate them according to the Quran and hłdith. Not only the message of reform was transmitted, but also some feminist ideas of the Egyptian Muslims were appreciated by some Indonesian Muslim. This was indicated in Aliran Baroe's reference to some Egyptian scholars, although without mentioning their names, to support their opinions. The support to this feminist ideas, for instance, can be seen in depiction of a bare-headed Egyptian woman, Abkaar Assegaf, in Aliran Baroe magazine. It also stated that face veiling had just remained in museums and considered the people who wanted to re-apply it as the wearing the cloth of corpses (pakaian mayit). It was also evident that the campaign of berguk (face veil), supported by Bin Yahya Mansoer, could not gain supports from Indonesian Muslim until his blood run out because of his shame. ${ }^{89}$

\footnotetext{
Aliran Baru atur sendiri dengan pantai buat dua-dua fihak. Di situ bisa kita bicarakan sepuaspuasnya atas jalan munazharah dan verslag-nya boleh kita sama-sama citak dan siarkan percuma atau dengan abayaran. Ajakan ini kalau mau dinamakan ajakan bercakar, ajak debat, ajak berkelahi dan sebagainya, boleh tidak ada halangan, asal pertemuan berhasil. Kalau betul ada di fibak kebenaran janganlah takut bertemu muka di satu majlis yang teratur dengan pakai juri dan anggotanya."

${ }^{86}$ Noer, the Modernist Muslim Movement, p. 91.

87 Pijper, Beberapa Studi Tentang Sejarah Islam, p. 129.

${ }^{88}$ For further information, see Federspiel, Islam and Ideology, pp. 117-120.

89 Aliran Baroe, no. 22 (Mei 1940), p. 19.
} 
Those debates explicitly showed how Indonesian Muslims searched their identity as an Indonesia Muslim. The proponents of veiling see that it was obliged for Muslim women to cover their heads and even their faces in order to bind Western cultures. On the other side, the opponents argued that Islam did not regulate women dressing because it was up to the local traditions. Further, they said that head and face veils were Arab tradition, instead of Islamic obligations.]

\section{Bibliography}

\section{Books and Articles}

'Uthmaæ, Sayyid . Lima Su'al di dalam Perihal Memakai Kerudung. Batavia: Self-published, 1899.

Adnan, Nurlela, Ermitati, and Rosnida M. Nur (eds). Kamus Bahasa Indonesia-Minangkabau. Jakarta: Balai Pustaka, 2001.

al-Mandzur, Ibn. Lisan al- 'Arab. Beirut: Dar Lisan al-`Arab.

Burhanuddin, Jajat. "Aspiring for Islamic Reform: Southeast Asian Request for Fatwas in al-Manar.” Islamic Law \& Society, Vol. 12 Issue 1 (Feb 2005): pp. 9-26

Djajaningrat, Hoesein. Atjeh-Netherland Wordenbook. II, 1934.

Effendi, Djohan. A Renewal Without Breaking Tradition: The Emergence of a New Discourse in Indonesi'a Nabdlatul Ulama During Abdurrabman W abid Era. Yogyakarta: Interfidei, 2008.

Eringa, F.S. Soendaas-Nederlands woordenboek. Dordrecht: Foris, 1984.

Federspiel, Howard M. Islam and Ideology in the Emerging Indonesian State: The Persatuan Islam, 1923 to 1957. Leiden: Brill, 2001.

Gibb, H. A. R., J.H. Kramers, E. Levi-Provencal, and J. Schacht (eds). The Encyclopedia of Islam. Leiden: Brill, 1986.

Hamka, "Mengabadikan Sebuah Pertemuan Dengan Sahabat." Panji Masyarakat. no. 25.

---------. Ayahku. Jakarta: Umminda, 1982.

Hassan, A. "Dari Hal Koedoeng Perempoean, Pergaoelannya, dan lainlainja." Pembela Islam, 43 (February 1932).

-------. Soal-Jawab Tentang Berbagai Masalah Agama. Bandung: C.V. Diponegoro, 1977. 
- Wanita Islam: Jilbab, di Podium, Jabatan Tangan. Bangil: Percetakan Persatuan, 1989.

Hsia, Heah Lee. The Influence of English on the Lexical Expansion of Bahasa Malaysia. Kuala Lumpur: Dewan bahasa and Pustaka, 1989.

Hurgronje, Snouck. Mekeka in the Latter Part of the 19th Century. Leiden: Brill, 1931. -.. The Achehnese. Leiden: Brill, 1906.

Kaptein, Nico J. G. "Southeast Asian Debates and Middle Eastern Inspiration: European Dress in West Sumatra at the Beginning of the Twentieth Century." in Eric Tagliacozzo (ed.). Southeast Asia and the Middle East: Islam, Movement, and the Longue Durée. Stanford University Press.

Marcoes-Natsir, L. "Profil Organisasi Wanita Islam Indonesia: Studi Kasus PERSISTRI." in L. Marcoes-Natsir \& J.H. Meuleman (eds). Wanita Islam Indonesia dalam Kajian Tekstual dan Kontekstual. Jakarta: INIS, Kumpulan Makalah Seminar Seri INIS XVII, 1993.

Minhaji, Akh. Ahmad Hassan and Islamic Legal Reform in Indonesia [188719587. Yogyakarta: Kurnia Kalam Semesta, 2001.

Moussay, Gerard. Dictionnaire Minangkabau-Indonesian-Français. Paris, 1995.

Noer, Deliar. The Modernist Muslim Movement in Indonesia 1900-1942. London: Oxford University Press, 1973.

Oosting, H.J. Soendasch-Nederduitsch woordenboek. Batavia: Ogilvie, 1879.

Peacock. Purifying the faith: the Mubammadiyah Movement in Indonesian Islam. California: University of Minnesota, 1978.

Pijper, G. F. "De vrouw en de moskee," in Fragmenta Islamica. Leiden: Brill, 1934.

---------. Beberapa Studi Tentang Sejarah Islam di Indonesia 1900-1950, translated by Turjimah and Yessy Augusdin. Jakarta: Penerbit Universitas Indonesia, 1984.

Poerwadarmita, W.J.S. Kamus Umum Babasa Indonesia. Jakarta: Perpustakaan Perguruan Kementrian P. \& K, 1954.

Pusat Pembinaan dan Pengembangan Bahasa Departemen Pendidikan dan Kebudayaan. Kamus Besar Bahasa Indonesia. Jakarta: Pusat 
Pembinaan dan Pengembangan Bahasa Departemen Pendidikan dan Kebudayaan, 1988.

Rajab, Muhamad. Perang Paderi di Sumatera Barat 1803-1838. Jakarta: Perpustakaan Perguruan Kementerian P \& K, 1954.

Ross, Heather Colyer. The art of Arabian costume: A Saudi Arabian profile. Fribourg: Arabesque, 1981.

Russell, Jones. Loan-words in Indonesian and Malay. Leiden: KITLV Press, 2007.

Safarwan, H. Zainal Abidin, Kamus Besar Bahasa Melayn. Kuala Lumpur: Utusan Publication and Distributor, 1995.

Salam, Salichin. K.H. Ahmad Dhalan: Reformer Indonesia. Jakarta: Jajamurni, 1963.

Steenbrink, Karel A. Pesantren, Madrasah, Sekolab: Pendidikan Islam dalam Kurun Moderen. Jakarta: LP3S, 1986.

Stillman, Yedida Kalfon. Arab Dress: A Short Story from the Dawn of Islam to Modern Times. ed. Norman A. Stillman. Leiden: Brill, 2000.

Wilkinson, R.J. Malay-English Dictionary. Mytilene: Salapaulos and Kinderlis, 1932.

\section{Newspapers}

Aliran Baroe. no. 16, November 1939; no. 17, December 1939; no. 17, November 1939; no. 18, December 1939; no. 18, January 1940; no. 20, March 1940; no. 21, April 1940; no. 22, Mei 1940; no. 23, Mei 1940; no. 23, June 1940; no. 23, June 1940; no. 28, November 1940; no. 34, May 1941; no. 36, July 1941.

Aliran Baroe. "Aliran Baru Kontra Siti Zubaidah.” no. 17, January 1940.

Aliran Baroe. "Mana Dia? Bergoeknya Toean Bin Yahya Masyhoer." No. 21, 1940.

Kaoem Moeda, No. 42, March 2, 1921 and March 7, 1921 